\title{
The Surtsey volcano geothermal system: An analogue to constrain elemental cycling in seamounts?
}

KLEIne, B.I. ${ }^{1}$, StefÁnsSOn, A. ${ }^{1}$, KJARTANSDÓtTIR, R. ${ }^{1}$, Prause, S. ${ }^{2}$, Weisenberger, T.B. ${ }^{2}$,

SVEINBJÖRNSDÓTTIR, Á.E. ${ }^{1}$, JACKSON, M.D. ${ }^{3}$, GUDMUNDSSON, M.T. ${ }^{1}$

${ }^{1}$ University of Iceland, Reykjavík, Iceland, barbarak@hi.is

${ }^{2}$ Iceland GeoSurvey, Reykjavík, Iceland

${ }^{3}$ University of Utah, Salt Lake City, USA

Surtsey, southern Iceland, is a young volcanic island that grew from the seafloor during explosive and effusive eruptions in 1963-1967. In 1979 and 2017, four cored boreholes were drilled 151-340 $\mathrm{m}$ into basaltic deposits that host a low-temperature $\left(\leq 50-150^{\circ} \mathrm{C}\right)$ seawater geothermal system. Surtsey provides a pristine environment to study water-rock interaction processes in a young seawater geothermal system that may serve as an analogue to lowtemperature seamount systems in the oceanic crust.

Elemental concentrations $\left(\mathrm{SiO}_{2}, \mathrm{~B}, \mathrm{Na}, \mathrm{Ca}, \mathrm{Mg}, \mathrm{F}\right.$, dissolved inorganic carbon, $\mathrm{SO}_{4}, \mathrm{Cl}$ ) and isotope contents $\left(\delta \mathrm{D}, \delta^{18} \mathrm{O}\right)$ indicate that the borehole waters originated from seawater that has been modified by reactions with the surrounding basaltic rock. These processes produce authigenic mineral formation in basaltic lapilli tuff deposits and a corresponding depletion of certain elements in the residual waters.

Reaction path modelling was performed to investigate the effect of temperature, associated basalt alteration and authigenic mineral formation on $\mathrm{SiO}_{2}, \mathrm{Mg}, \mathrm{SO}_{4}$ and $\mathrm{Ca}$ chemical fluxes from and to the geothermal water in the submarine and subseafloor deposits of the island. The calculated annual chemical flux values are similar to those flux values previously reported for much older seamount systems hosted in the igenous oceanic crust. The calculated Surtsey fluxes imply that water-rock interaction produces authigenic minerals that serve as important sinks of seawaterderived $\mathrm{SiO}_{2}, \mathrm{Mg}$ and $\mathrm{SO}_{4}$. In contrast, the uptake of $\mathrm{Ca}$ by authigenic minerals is limited and thus water-rock interaction accompanied by dissolution of basaltic glass and primary crystal fragments, provides a significant source of $\mathrm{Ca}$.

Extrapolating our flux estimates to the global scale shows that low-temperature alteration could effectively influence the elemental budget of seawater and oceanic crust. The presented modelling provides insights into discharge chemistries and chemical fuxes in seamount systems but could also be a valuable tool to study porewater evolution within the deeper oceanic crust at elevated temperatures. 